\title{
Can gender differences in the educational performance of 15-year old migrant pupils be explained by the gender equality in the countries of origin and destination?
}

Citation for published version (APA):

Dronkers, J., \& Kornder, N. (2013). Can gender differences in the educational performance of 15-year old migrant pupils be explained by the gender equality in the countries of origin and destination? Maastricht University, Graduate School of Business and Economics. GSBE Research Memoranda No. 018 https://doi.org/10.26481/umagsb.2013018

Document status and date:

Published: 01/01/2013

DOI:

10.26481/umagsb.2013018

Document Version:

Publisher's PDF, also known as Version of record

Please check the document version of this publication:

- A submitted manuscript is the version of the article upon submission and before peer-review. There can be important differences between the submitted version and the official published version of record. People interested in the research are advised to contact the author for the final version of the publication, or visit the DOI to the publisher's website.

- The final author version and the galley proof are versions of the publication after peer review.

- The final published version features the final layout of the paper including the volume, issue and page numbers.

Link to publication

\footnotetext{
General rights rights.

- You may freely distribute the URL identifying the publication in the public portal. please follow below link for the End User Agreement:

www.umlib.nl/taverne-license

Take down policy

If you believe that this document breaches copyright please contact us at:

repository@maastrichtuniversity.nl

providing details and we will investigate your claim.
}

Copyright and moral rights for the publications made accessible in the public portal are retained by the authors and/or other copyright owners and it is a condition of accessing publications that users recognise and abide by the legal requirements associated with these

- Users may download and print one copy of any publication from the public portal for the purpose of private study or research.

- You may not further distribute the material or use it for any profit-making activity or commercial gain

If the publication is distributed under the terms of Article 25fa of the Dutch Copyright Act, indicated by the "Taverne" license above, 
Jaap Dronkers, Nils Kornder

Can gender differences in the educational performance of 15-year old migrant pupils be explained by the gender equality in the countries of origin and destination?

RM/13/018

\section{GSBE}

Maastricht University School of Business and Economics

Graduate School of Business and Economics

\section{P.O Box 616}

NL- 6200 MD Maastricht

The Netherlands 


\title{
Can gender differences in the educational performance of 15 -year old migrant pupils be explained by the gender equality in the countries of origin and destination? ${ }^{1}$
}

\author{
Jaap Dronkers \& Nils Kornder \\ University of Maastricht (Netherlands)
}

\begin{abstract}
We try to explain the differences between the performance (in both reading and math) of 8430 15-year-old daughters and 8526 15-year-old sons in 17 Organisation for Economic Cooperation and Development destination countries across Europe and Oceania with the PISA 2009 data from 45 origin countries or regions. In addition to the level of societal gender equality of the origin and destination countries (the gender empowerment measure, or GEM) we use macro indicators of the educational systems, economic development, and religions of the countries of origin. We find that migrant daughters from countries with higher levels of gender equality have higher reading scores than comparable migrant sons (but this is not the case for math scores). In addition, the higher the level of gender equality in the destination countries, the lower the reading and math scores of both the male and female migrants' children in their destination countries. Further analyses suggest that the difference between the levels of gender equality, rather than the levels themselves, of the origin and destination countries explains more of the educational performance of both female and male migrant pupils. Our results also show that the low level of gender equality in Islamic origin countries is a sufficient explanation of the low educational performance of Islam male and female migrants' pupils. Finally, migrants' daughters seem to perform slightly better educationally than comparable migrants' sons.
\end{abstract}

\section{Introduction}

Overall, the educational position of migrant children is well documented but there is far less systematic documentation about the educational position of migrant sons and daughters in relation to characteristics of their country or region of origin. While Levels and Dronkers (2008) studied that relation, they neglected the educational performance of the male and female migrants' children of migrants. Even though successive papers with PISA 2003 data (Levels, Dronkers, \& Kraaykamp, 2008) and PISA 2006 data (Dronkers \& de Heus, 2013a, $2013 \mathrm{~b}$ ) carried out far more sophisticated analyses by including macro features of the origin and destination countries, possible gender differences between the educational performance of the daughters and sons of migrants continued to be ignored. In addition, other researchers of the educational performance of migrant children with a double perspective (both origin and destination) ignored possible differences between male and female pupils. Only recently has a group of researchers started to address these differences (Fleischmann \& Kristen, forthcoming), but they could only use national data for their cross-national analysis, thus limiting comparisons.

In an earlier paper (Kornder \& Dronkers, 2012) we addressed the gender differences of the educational performance of migrant children with the data of the PISA 2009 wave. This earlier paper described these gender differences and their variations by origin and destination, controlling for the educational performance of native female and male pupils in their

\footnotetext{
1 We thank the participants of the 2012 ECSR/Equalsoc Conference in Stockholm and the members of the Dutch Interuniversitaire Werkgroep Sociale Ongelijkheid en Levensloop (Interuniversity Study Group on Social Stratification and Life course) for their very useful comments on earlier, more extensive analyses of gender variation in the educational performance of migrant children. Jan Feld's and Johan's comments of on an earlier version of this paper were also useful.
} 
destination countries. The principal conclusion was that female migrant pupils have higher reading and math scores than comparable male migrant pupils and these gender differences among migrant pupils in reading and math scores are larger than among comparable native pupils. However, no clear relation was found between gendered performance differences and the level of economic development and traditionalism of the origin countries. This last result contradicts the assumption that the poverty level and traditionalism of the origin region can explain the gender variation in the educational performance of migrant pupils.

In this, subsequent paper, our analysis is more sophisticated analysis and replaces the destination and origin countries by an indicator for societal gender equality (Gender Empowerment Measure; GEM), which explains the gender variation in the educational performance of migrant children better than poverty and traditionalism. We also include other macro indicators for the levels of development, the educational opportunity structure, and the dominant religions of the origin countries to validate the effects of societal gender equality.

This paper's research question is: can gender differences in the educational performance of migrant pupils be explained by the societal gender equality in their countries of origin and destination?

\section{Multiple origins and destinations}

Since migration is intrinsically a transnational phenomenon, it should be studied accordingly (Portes, 1999). Migrant parents and children from various countries of origin move to various countries of destination. Therefore, instead of relying on observations of multiple-origin groups in a single destination or single-origin groups in multiple destinations, our analyses simultaneously compare multiple origins in multiple destinations. Since this design disentangles the effects of the characteristics of the countries from which migrants come from (origin effects) and the characteristics of the countries to which they migrate (destination effects), it is extremely useful in gaining insight into the factors influencing migrant outcomes such as educational performance. This paper applies this double comparative perspective, based on a multilevel approach, as developed by van Tubergen, Maas, and Flap (2004). This double comparative perspective seems obvious for a correct analysis of migrant outcomes and a workable policy, but that is unfortunately not the case. Influential reports by the Organisation for Economic Co-operation and Development (OECD) on migrant pupils using PISA data (OECD, 2006, 2012) ignore the available origin of migrants and the same holds for the most recent European Union policy paper on migrants and education (European Commission, 2008).

\section{Societal gender equality and the educational outcomes of male and female migrant pupils}

Gender variation in educational performance is a classic topic in the educational sciences. The expansion of the educational system and the gradual abolishment of gender barriers in the educational careers during the 20th century should have abolished these gender variations, but resulted instead in a trend of female advantages in secondary education in OECD countries (for overviews, see Buchmann, DiPrete, \& McDaniel, 2008; van Langen, 2005). The strength of these gender variations in educational performance is not equal across OECD countries. Moreover, the gender variation in educational performance is also domain specific: Girls do far better in reading, while boys still score higher in math (Marks, 2007). A great deal of research has tried to explain cross-national gender variations in reading and math scores (Guiso, Monte, Sapenza, \& Zingales, 2008; van Langen, 2005). However, since a review of this line of research is outside the scope of this paper, we simply refer to the above-mentioned overviews. It is important to note, though, that the cross-national gender variation in 
educational performance does not seem related to the level of poverty and traditionalism of the OECD countries.

Similar gendered variation exists in the educational performance of the children of migrants (OECD , 2006, 2012) but until now this cross-national gendered variation has hardly been analyzed and is only descriptive. Moreover, the description of gendered variation in the educational performance of the children of migrants is mostly limited to single-country studies (Abada \& Tenkorang, 2009), which do not always include the gendered variation in the educational performance of the native pupils (Feliciano \& Rumbaut, 2005). Consequently, non-descriptive studies on cross-national gender variation in educational performance are scarce. We know only of Fleischmann and Kristen's (forthcoming) study, which uses national data for a cross-national analysis of four indicators of the educational performance of male and female migrant children.

Kornder and Dronkers (2012) did not find the level of poverty or traditionalism of the origin region to be related to gender variation in the educational performance of migrant pupils. Although a large number of alternative speculative hypotheses could be formulated, based on assumptions made by policymakers about educational performance differences between migrant sons and daughters, we restrict ourselves to two simple hypotheses that assume that the educational performance of girls will be associated with a more equal gender balance in their societies of origin and destination. The (in)equality in opportunities and resources between the two sexes within a country may better predict gender variation in educational performance than the level of poverty or traditionalism of that country. Gender relations are not only influenced by the poverty and traditionalism of origin countries, but can also be related to the culture and religion of these origin societies. Therefore, we focus on societal gender equality in the origin and destination countries to explain the gender variation in educational performance. We control for educational and societal macro characteristics and the dominant religions of the origin countries to test for spurious relations between societal gender equality and educational performance.

\subsection{Effect of societal gender equality in the origin countries on female educational performance}

The majority or at least a large minority of migrants to OECD countries move from societies with less gender equality to societies with a more equal power balance between the sexes. Girls in societies with less gender equality have fewer educational opportunities compared to their brothers. The reasons for this unequal gender power balance include religious and/or cultural traditions, as well as the fact that educational investments in boys are more profitable for parents in these societies than the same educational investments in girls (Fuligni, Tseng, \& Lam, 1999). Moreover, this lesser gender equality of female migrant pupils' origin societies can still limit their educational performance due to more obligations at home and pressure for an early marriage. Because parents who have migrated socialize their children, the gender norms of their origin countries will influence those of their children, even if these children are born in the country of destination. We then assume Hypothesis 1, that the greater the gender equality in the origin country, the higher the educational performance of migrant daughters in comparison with that of migrant sons.

\subsection{The effect of societal gender equality in destination countries on female educational performance}

The daughters of migrant from origin societies with lesser gender equality can use the greater educational opportunities in their destination societies to escape from the male bias of the religious and/or cultural traditions of their origin societies (Abada \& Tenkorang, 2009) and therefore perform better in education. Greater gender inequality in the origin country is 
related with closer supervision and stricter parental monitoring of daughters, due to their value as a virgin in the marriage market. This closer supervision and stricter parental monitoring of the migrant daughters compared to that of migrant sons can also strengthen the discipline of the migrant daughters to a greater degree, thus positively affecting their educational opportunities in destination countries with more gender equality (Feliciano \& Rumbaut, 2005; Zhou \& Bankston, 2001). Therefore we formulate Hypothesis 2: The educational performance of migrant daughters in destination countries with greater gender equality is higher than that of migrant sons.

\section{Data and variables}

\subsection{PISA 2009}

Since 2000, the OECD has conducted large-scale tri-annual tests among 15-year-olds living in its member and partner states to assess pupils' mathematical, reading, and scientific literacy. In doing so, the OECD has aimed to determine the extent to which pupils near the end of their compulsory education have acquired knowledge and skills essential for full participation in society. Alongside information on pupils' educational performance, PISA provides information on their individual characteristics (e.g., parental education and careers, resources available at home, languages spoken at home, and the birth countries of both the parents and the pupil) through the administration of pupil and principal questionnaires. This paper uses the latest PISA wave of 2009 (OECD, 2010).

This study focuses on reading abilities (the dependent variable), the focus of the PISA 2009 wave, but we use the math test as well to determine whether we can generalize our results. A 390-minute pencil-and-paper test was developed. However, since it would not be sensible to administer a test more than six hours long to an individual pupil, 13 largely comparable item clusters (seven for reading, three for mathematics, and three for science) of two hours' duration each were derived from the core test. These test booklets were allocated to individual pupils according to a random selection process, requiring them to answer multiple-choice as well as open questions. In some countries, an additional 40-minute test was administered, covering tasks related to reading and understanding electronic texts.

Since two test booklets can never have exactly the same average difficulty, item response modeling was used to establish comparable reading results across pupils. Item response modeling involves the construction of several plausible reading values for each pupil. Thus, instead of obtaining just one score to indicate each pupil's reading ability, five possible reading score values are estimated per pupil. For each pupil, we averaged the five plausible values to calculate a composite score. The composite scores were standardized using an average of 500 and a standard deviation of 100 for all OECD pupils (native and nonnative). Tables 1 and 2 show the reading and math test scores for male and female migrants, respectively, differentiated by the origin country or region and the country of destination.

To take into account the variance between these five plausible values for math and reading, we also computed their standard error. We weighted the migrants so that each OECD destination country has the same number of migrants (1000), to avoid OECD countries with large sample sizes or with large numbers of migrants dominating the analyses without increasing the total numbers of migrants in the sample.

\subsection{Pupils' country of origin and migrant status}

Since specific information on the country of birth of both a pupil and the parents is necessary to determine the pupil's country of origin, destination countries that did not allow enough specificity in birth countries were omitted. For instance, when asking about the country of origin, the United States only provided the options United States of America and another country. Among destination countries that did provide enough variety in birth country options 
to be included in our analysis, the question was not consistently asked. Participating countries had the possibility of determining a set of answers in advance, allowing countries to include in the dataset their most important groups of migrants. For instance, as possible countries of origin the German questionnaires listed Croatia, Greece, Italy, Macedonia, Montenegro, Poland, Serbia, Slovenia, Turkey, and one of the former USSR republics, while New Zealand listed Australia, China, Korea, South Africa, the United Kingdom, and Samoa. Therefore, data from only 17 of all OECD countries were useful for the analysis (we deleted Turkey, because it had fewer than 50 male and female migrant pupils with a known origin country, and Mexico, because it is an outlier in many aspects). ${ }^{2}$ All OECD destination countries with relevant information about the countries of birth are given in Table 1.

\section{[Table 1 about here]}

To determine a pupil's country of origin, several decision rules were used based upon the pupil's birth country and the birth countries of both parents. ${ }^{3}$ To capture as many respondents as possible, we also included aggregate origin areas or combinations of countries that were sufficiently specific as countries of origin for the purpose of this analysis. Most destination countries allowed for the selection of at least one aggregate origin area or a combination of countries. For example, Germany, Greece, Israel, and the Netherlands allowed for the origin selection one of the former USSR republics. Belgium offered the combination Maghreb, while other countries, such as the Netherlands, listed only the option of Morocco. We combined these migrants in an equivalently labeled composite category. In some cases we also combined origin countries into larger units, separating former Yugoslav or USSR states into the former Yugoslavia or the former USSR, respectively, and grouping the Czech Republic and Slovakia together, the Maghreb countries ${ }^{4}$ together, and all the Caribbean countries together. In total, using decision rules to identify pupils' countries of origin and migrant status yields a final sample of 8430 female and 8526 male migrant pupils originating from 45 different origin countries and regions (see Table 2 for a full list of all uncombined origin countries and regions; Kornder \& Dronkers, 2012).

\subsection{The dependent variable}

The 2009 PISA wave focuses on reading literacy with a large scale but also contains a smaller scale for math literacy. Table 1 reports the reading and math scores and number of cases of male and female migrants in all the available OECD destination countries. Table 2 shows the reading and math scores and number of cases of male and female migrants in all the origin countries and regions.

\section{[Table 2 about here]}

Considering destination effects, Table 1 shows that female and male migrant pupils in New Zealand have the highest reading and math scores compared to migrants in other destination

\footnotetext{
${ }^{2}$ The OECD allows participating countries to propose their own birth country categories. As a result, the origin countries of the different destination countries depend partly on the quality of the available categories. To account for this possible bias, we compared, as much as possible, the origin countries in PISA with national statistics. In most cases the largest migrant groups identified by the statistical offices are also represented in our PISA data. Since the PISA data do not oversample migrant pupils, smaller migrant groups (if asked for) are understandably not always present in our data. There are no indications that this selectivity (only the largest migrant categories of the destination countries) has produced a bias, because small migrant categories in the destination countries hardly influence the results.

${ }^{3}$ The decision rules are available on request from the first author.

4 Algeria, Morocco, and Tunisia.
} 
countries (female 556/528; male 520/542), followed by migrant pupils in Scotland (female 534/515; male 531/542) and Australia (female 542/530; male 507/530). Female and male migrant pupils in Denmark have the lowest reading (430/401) and math scores (411/431), followed by Austria (female 451/541; male 412/467). Regarding origin effects, Table 2 shows that female and male migrant pupils from India have the highest scores (female 560/528; male 573/567), Korea (female 533/542; male 505/559), followed by South Africa (female 558/532; male 514/536) and the United Kingdom (female 558/531; male 527/545). Female and male migrant pupils from Cape Verde have the lowest reading and math scores (female 409/406; male 343/395), followed by Lebanon (female 421/394; male 406/434), Ethiopia (female 422/364; male 394/376), and Iraq and Iran (female 423/406; male 420/450).

Both Tables 1 and 2 show that there is sufficient cross-destination and cross-origin variation in the educational performance of male and female migrant pupils for further combined multilevel analysis with a double perspective.

\subsection{Individual-level variables}

Table 3 summarizes all relevant micro and macro variables, including the minimum and maximum scores and the mean and standard deviation for pupils with a migration background and a known country or area of origin.

\section{[Table 3 about here]}

After identification of a pupil's country of origin, we identify the pupil's migrant status. Pupils with at least one parent born in a country different from the destination country were identified as migrants. Migrant pupils were classified as first generation (reference category) when they were born outside the destination country and as second generation when at least one of their parents was born abroad. This distinction between first- and secondgeneration migrants deviates from that of Portes and Rumbaut (2001), who classify migrant generation status based on age upon arrival in the destination country. However, we believe that this distinction is cross-nationally clearer and less likely to underestimate the importance of pre-school socialization. Migrant pupils whose generation could not be determined were taken into account by creating a missing generation dummy variable.

Given that we use PISA data on 15-year-old migrant pupils, probably about half of the first generation of migrant pupils arrived before their sixth year in their destination country. Unfortunately, the age of arrival is not available in PISA 2009 to check this. Using 2006 PISA data, however, Song and Robert (2010) reported that $21 \%$ arrive when they are between zero or one year old, $28 \%$ arrive between two and five years old, $26 \%$ between six and 10 years old, and $25 \%$ between 11 and 15 years old. The majority of these 15 -year-old pupils had the majority of their formal schooling only in the destination country. Song and Robert (2010) and Dronkers and de Heus (2013a, 2013b) showed that the older children are upon arrival in the destination country, the lower their educational performance: They are more socialized in the culture of the origin country and have less experience of the educational system of the destination country. Unfortunately, due to the omission of the age of arrival, we cannot include this variable in our analysis. However, Song and Robert (2010) and Dronkers and de Heus $(2013 a, 2013 b)$ showed that the addition of this variable does not substantially change the coefficients of the other variables.

The dummy variable official language of destination country spoken at home distinguishes between migrant children who speak one of their destination country's official languages at home and those who speak a foreign language. A language missing dummy variable was also created. 
We combine the generation variables and the indicator of the language spoken at home into seven dummy variables: first generation and official language, first generation and foreign language, first generation and unknown language, second generation and official language, second generation and foreign language, and second generation and unknown language.

We use a number of additional variables to account for the social and cultural status of migrant pupils. First, we control for the pupils' parental environment by using the index of the economic, social, and cultural status of the parents (ESCS). This variable represents a composite index created in the PISA dataset of the parents' occupational status (Ganzeboom, de Graaf, Treiman, \& de Leeuw, 1992), the parents' educational level (United Nations Educational, Scientific and Cultural Organization, 2006), and the presence of any material or cultural resources at the pupils' homes. ${ }^{5}$ This combination of the parents' occupational status and educational level together with resources at home produces the strongest indicator of parental environment (OECD, 2010). If one or more of these variables were missing for a respondent, we imputed the ESCS value by taking the average of the prior pupil and the next after sorting all cases based on destination country, generation, country of origin, International Standard Classification of Education (ISCED), International Socio-economic Index of occupational status (ISEI), and home possessions. The ESCS score was standardized such that the OECD average was set to zero.

Second, we controlled for the effects of family structure on scholastic performance. Since a previous analysis revealed that migrant pupils from single-parent families perform worse, on average, than pupils with both parents (Dronkers \& de Lange, 2012), we include a nuclear family dummy variable that measures whether children live in two-parent households. Those pupils with other family structures are the reference group.

Third, we included a dummy variable labeled one parent born in destination country to identify pupils who had one migrant and one native-born parent; pupils with two nonnative parents represent the reference group. This is a way of controlling for the effects of having a presumably stronger relation with the society and culture of the destination country when one parent is a native. A corresponding mixed marriage missing dummy variable was introduced to compare pupils for whom the birth country of one of the parents was missing with pupils for whom both parents are non-native.

\subsection{Gender equality macro variable $e^{6}$}

The GEM evaluates women's participation and decision-making ability in political and economic forums. Ranging from zero to 100, it combines variables such as women's share of parliamentary seats and ministerial positions, as well as managerial, senior official, and legislative jobs; their share of technical and professional jobs; and gender income differences. This variable was centered on its grand mean for the multilevel analyses. We added a GEM score for both the origin and destination countries.

\subsection{Educational opportunity macro variables}

4.6.1. Years of Compulsory Education (YCE)

The YCE variable refers to the duration of compulsory schooling in countries of origin. On average, for all origin countries and areas in our data, pupils are obliged to attend school for nine years. The mandatory length of schooling varies considerably between origin countries,

\footnotetext{
5 The measure consists of the presence of a desk, a private room, a quiet place to study, a computer, educational software, Internet access, literature or poetry, art, books that can be of use when doing schoolwork, a dictionary, a dishwasher, and the presence of more than 100 books in the house.

${ }^{6}$ More information about the macro-variables is given in Appendix A.
} 
from four to 12 years. This variable was centered on its grand mean for the multilevel analyses.

\subsubsection{Expected Years of Schooling (EYS)}

The EYS variable represents the expected number of years a child of school entrance age will spend in school and university, including grade repetitions, when current enrollment patterns in all educational levels (primary, secondary, post-secondary non-tertiary, and tertiary) remain the same. This variable was centered on its grand mean for the multilevel analyses.

\subsection{Societal macro variables.}

\subsubsection{Human Development Index (HDI)}

A country's level of economic development was gauged by its HDI. Ranging from zero to $100,{ }^{7}$ the HDI combines national information on peoples' life expectancies; adult literacy rates; gross enrollment ratios in primary, secondary, and tertiary education; and gross domestic product (GDP). This variable was centered on its grand mean for the multilevel analyses. $^{8}$

\subsubsection{Religion}

To take into account the origin countries' religious backgrounds, dummy variables were created to indicate whether or not at least $40 \%$ of the countries' inhabitants are Latin Christian, Eastern Orthodox (Ethiopia, Macedonia, Greece, Romania, the USSR), Hinduism (India), or Islamic (Afghanistan, Albania, Bangladesh, Iran, Iraq, Lebanon, Maghreb, Pakistan, Somalia, Turkey). Countries in which no religious denomination has the support of at least $40 \%$ of the population are classified as non-religious (China, the Czech Republic, Estonia, Korea, Vietnam). Similarly, if two religious groups are represented by at least $40 \%$ of the population, the country is regarded as mixed (e.g., Bosnia and Herzegovina, Suriname). Due to our combination of countries with diverse religions (e.g., the former Yugoslavia and USSR), these religious macro variables become variables at the individual level.

\subsection{Native reading or math score of the country of destination}

We use one additional macro indicator for the destination countries: the native reading or math score. This indicator is the average PISA score of the total native male or female population. This variable serves to approximate the quality of the destination country's educational system.

\section{Methods}

Using individual-level techniques on data with multiple levels will underestimate the standard errors of the macro level effects and parameters can then misleadingly appear to be significant (Raudenbush \& Bryk, 2002; Snijders \& Bosker, 1999). Cross-classified multilevel regression analyses are appropriate for analyzing non-hierarchically structured data. We used iterative generalized least squares estimation techniques from the statistical analysis program MLwiN to estimate the models. Although originally designed to fit hierarchical models, the iterative generalized least squares approach can also be adapted to non-hierarchical data structures. At the lowest level we include the standard error of the reading or math test as an error term of the equation.

\section{Results for reading scores}

Table 4 shows the results from the multilevel analyses for the reading scores of migrant children. Section 6.1 presents a model without the gender equality score to ensure that the

\footnotetext{
7 Transformed from zero to one into zero to 100 .

${ }^{8}$ More information about the computation of the avergae HDI score for combined countries of origin, see Appendix B.
} 
results are not caused by individual characteristics, because the latter are always the most powerful explanation of variation in educational performance, for migrant children as well. Sections 6.2 to 6.4 discuss the effects of the GEM score on educational performance, as assumed by our hypotheses. Sections 6.5 and 6.6 introduce additional control variables at the macro level to ensure that the effects of gender equality are caused by these macro characteristics.

[Table 4 about here]

\subsection{Individual characteristics}

The first model includes the gender and the individual characteristics of the migrant pupils. As one might expect, the parental ESCS and a nuclear family have positive effects on pupils' reading scores, while speaking a language other than the destination country's official language(s) has negative effects. We added two interactions, between gender and a nuclear family as well as between gender and second-generation same language because in additional analyses these two interactions are significant (see Appendix C). Second-generation female pupils who speak the destination country language at home have only slightly higher reading scores than comparable second-generation male pupils. A nuclear family has a positive effect on the reading scores of migrant sons and daughters, but it is stronger for male migrant pupils than for female migrant pupils, resulting in a seven-point difference. The gender parameter is positive, which implies that female migrant pupils have a reading score nearly 44 points higher than male migrant pupils do. This is slightly higher than the difference in the reading scores between female and male native pupils (37 points). The parameter of the average native score is large and positive but not significant in model 1 . However, it is significant in the later models.

\subsection{Gender equality in origin countries}

We add the GEM of the origin country and its interaction with gender in the second model. This addition hardly affects the parameters of the independent variables, which were already included in the previous model. The effect of the GEM of the origin country is significant for male migrant pupils $(0.35)$ and the interaction between this variable and gender is also significant: The total strength of GEM is 0.49 for female migrant pupils. ${ }^{9}$ This significant interaction supports our first hypothesis, that is, the greater the gender equality in the origin country, the higher the educational performance of migrant daughters in comparison with that of migrant sons. It also means that male pupils from origin countries with higher levels of gender equality perform better than comparable male pupils from origin countries with lower levels of gender equality.

\subsection{Gender equality in destination countries}

In model 3 we replace the origin GEM scores and their interaction with gender with the equivalent variables using the GEM scores of the destination countries. The effect of the GEM of the destination country is significant but negative and equal for both male and female migrant pupils because its interaction with gender is insignificant. This finding contradicts our second hypothesis, the higher the level of gender equality in the destination country, the higher the educational performance of migrant daughters in comparison with that of migrant sons. This addition hardly affects the parameters of the independent variables, which were already included in model 1, with one exception: The effect of the average native reading score becomes significant and positive. This finding suggests that the quality of the education

\footnotetext{
${ }^{9}$ Here 0.35 (GEM origin) + 0.14 (GEM origin * Female).
} 
in the destination country is important for the educational performance of migrant pupils, while a higher level of gender equality in the destination country seems to harm their performance. An analogous equation, but without the average native reading score (not shown here), still produces a negative but hardly significant effect of the GEM of the destination country, while the effect of the interaction between the GEM of the destination country and being female remains small and insignificant.

\subsection{Gender equality in both the origin and destination countries}

Model 4 contains the indicators of gender equality for both the origin and destination countries. They are moderately correlated $(0.11)$ and their inclusion hardly changes the results of the early models. The first hypothesis, about the positive effect of gender equality in the origin country on the educational performance of daughters of migrants, is therefore supported, while the second hypothesis, about the positive effect of gender equality in the destination country, is rejected.

\subsection{Gender equality and other macro characteristics of origin countries}

Model 5 adds three other macro characteristics of the origin countries that can explain the positive effect of the gender equality in these origin countries: HDI, YCE, and EYS. However, adding these three indicators changes the positive effect of the gender equality in the origin countries, because its parameter becomes insignificant. However, the assumed positive effect of the interaction variable GEM origin*Female remains significant. None of the added indicators has a significant effect as long as the GEM score of the origin country is included in the equation of model 5. The same holds for their interaction terms with gender (see Table $\mathrm{C} 1$ in Appendix C). If we delete the GEM scores from the equation, the effects of the HDI, YCE, and EYS of the origin country become positive and significant $(0.42 * *(0.18) / 3.52 * *(1.36) / 1.70(0.80))$. This implies that the gender empowerment score is a better predictor of the developmental level of origin countries than more traditional indicators, such as HDI.

\subsection{Religion and gender equality}

Gender relations are not only related to educational opportunities and the quality of life in the origin country, but are also partly influenced by religious norms and attitudes. Origin countries with Latin Christianity as their dominant religion have high GEM scores, while origin countries with Islam as their dominant religion have low GEM scores. Although the religions and GEM scores of origin countries are highly correlated, the correlations are not too strong (see Table $\mathrm{C} 4$ in Appendix C). To obtain model 6, we add the dominant religion of the origin country to model 4 to test whether significant effects of the GEM of origin or destination countries can be partially explained by religious factors.

The addition of the dominant religion does not change the effect of the GEM of the origin country and the effect of the interaction term GEM origin * Female remains significant. The effect of the GEM of the destination country becomes smaller and insignificant, which suggest that migrants in destination countries with the highest gender equality came more often from origin countries with Orthodox Christianity or mixed religions as the dominant religion. Thus, the different religious compositions of migrants to destination countries with different levels of gender equality can explain the unexpected negative effect of the GEM score of the destination country. None of the interaction terms of religion and gender is significant (see Table C1 in Appendix C). Thus the first hypothesis, about the positive effect of gender equality in the origin country on the educational performance of daughters of migrants, remains to be supported, while the second hypothesis, about the positive effect of gender equality in the destination country, must be rejected. 
We have also estimated a model that includes individual characteristics of the pupils and the dominant religion and their interaction terms with gender (see Table C2 in Appendix C). The omission of the indicators of gender equality increases the parameters of the dominant religion in comparison with those of model 6. The negative effects of Islam and Eastern Christianity become stronger and significant, while the positive effect of Hinduism diminishes. This finding suggests that part of the negative effects of Islam and Eastern Christianity on the educational performance of male and female pupils are related to their religious values and norms concerning the unequal position of women in society. This result also suggests that female and male Hindu pupils would achieve even higher educational performances if their religious values and norms about the position of women in society were more equal.

\section{Math score results}

Table 5 shows the results of multilevel analyses analogous to those in Table 4, but with math scores as the dependent variable. It is important to test our hypotheses for math scores because native male pupils score higher on the math test than native female pupils $(514 / 500)$, while native female pupils have higher reading scores than native male pupils (509/472). Thus, the use of the reading score as the sole indicator of educational performance can lead to results that cannot be generalized to other indicators of educational performance.

\section{[Table 5 about here]}

Our first hypothesis - the greater the gender equality in the origin country, the higher the educational performance of migrant daughters in comparison with that of migrant sonsis only partly true if we use math scores as an indicator of performance. Only in model 5, controlling for other societal macro indicators and their interaction with gender, does the interaction term between the GEM origin and female become significant. Thus, although math scores provide some support for the first hypothesis, reading as the educational performance indicator provides far more.

Our second hypothesis - the educational performance of migrant daughters in destination countries with higher levels of gender equality is higher than that of migrant sons - is also rejected if math scores are the educational performance indicator. The interaction term between the GEM destination and female is never significant in any of the models. An analogous equation, but without average native reading scores (not shown here, but available on request), yields a small and insignificant effect for the GEM of the destination country and the effect of its interaction with female also remains insignificant.

Other results of our analysis are 1 . The dominant religion of the origin country cannot explain the positive effect of the GEM of the origin country for either male or female migrant pupils; 2 . The GEM destination has a negative effect on the educational outcomes of migrant pupils, irrespective of gender. This is more or less analogous to having math or reading as the educational performance indicator; 3 . Migrant boys have math scores about eight points higher than migrant girls, which is slightly less than the 14-point difference between the math scores of native male and female pupils; 4. Overall, the results of the analyses of gender differences in both reading and math scores show strong similarities, although in some areas substantial differences persist.

\section{Conclusions}

We analyze the educational performance of 8430 15-year-old daughters and 8526 15-year-old sons in destination OECD countries across Europe and Oceania with PISA 2009 data. We distinguish 45 origin countries or regions and 17 OECD destination countries. We use a 
number of macro indicators for the countries of origin and destination relating to their levels of gender equality, educational systems, economic development, and religions.

\subsection{Gender equality in the origin country}

Our first hypothesis assumes that the greater the gender equality in the origin country, the higher the educational performance of migrant daughters in comparison with that of migrant sons. This is true for reading and only partially for math. Migrant daughters coming from countries with a higher level of gender equality have higher reading scores than comparable migrant sons, but this is not necessarily true for math scores. The deviation may be explained by the different meanings of language and math for boys and girls and the fact that good math performance is less contradictory with traditional male gender roles than good reading performance. Another explanation may be that learning a language relates more to the family and thus more to the origin country and its gender norm, while learning math is more related to school and thus less to the country of origin but more to the gender roles of the destination country.

The positive effects of gender equality on the performance of both sexes cannot be explained by other macro indicators related to the economic development or educational system of the origin country, nor can the dominant religion of the origin countries explain this positive effect of gender equality. A possible explanation of the predicting power of the GEM indicator is that gender equality better reflects a society's level of development more than abstract indicators such as income, life expectancy, and level of education obtained.

\subsection{Gender equality in destination countries}

Our second hypothesis - that the educational performance of migrant daughters in a destination country with a higher level of gender equality is higher than that of migrant sons in the same destination country - is not supported by our results, neither for reading nor for math. We find that the greater the level of gender equality in the destination country, the lower the educational performance of both male and female migrant children in the destination country. We assume a positive effect for the GEM only for the female migrant pupils, but no negative effect that has the same strength for both male female migrant pupils. This negative effect of the destination country's GEM on the performance of migrant pupils cannot be fully explained by the lower variance of the GEM score for destination countries (see Table 3), because the latter increases the chance of insignificant parameters but not the chance of significant negative parameters. This negative effect of the destination country's GEM cannot be explained by the educational background of the migrants to destination countries with high GEM scores because our equations control for the socioeconomic background (including education) of the parents and other economic and cultural macro characteristics of the origin countries.

A more plausible explanation for this unexpected result may be that parents who migrate to societies with higher levels of gender equality feel a greater distance from these alien, more liberal societies and are thus less able to supervise and monitor their daughters and sons. A consequence of less effective parental supervision and monitoring is a lower level of discipline for both their sons and daughters. We tried to make this distance explanation plausible through an additional analysis that replaces the GEM of the origin or destination country in model 4 by the difference in the GEM scores of the origin and destination countries. The results are given in Table C3 of Appendix C. The distance in the GEM scores between the origin and destination countries seems to be the best explanatory variable, while the GEM scores for the origin and destination countries separately do not add much to the equation. In other words, it is not the discrete levels of gender equality in the origin and 
destination countries that are the most relevant explanation for the educational performance differences between female and male migrant pupils but, rather, the difference between them.

\subsection{Religion as a factor in the educational performance of migrant sons and daughters}

As shown in Tables 4 and 5, the level of gender equality in the origin country is not the sole explanation of the educational differences between female and male migrant pupils. The dominant religion of the origin countries is also a significant factor. Educational performance is higher for migrant children coming from origin countries without a dominant religion or with Hinduism as its dominant religion compared with migrants coming from countries with Latin-Christianity as the dominant religion. These outcomes are controlled for gender equality in the origin and destination countries, in addition to individual characteristics such as parental background and migration generation. There are no differential effects of dominant religion on migrant daughter and sons as long as we control for gender equality in the origin countries (see Table C1).

Although the PISA data do not allow us to test these outcomes with the precise religions of the pupils and their parents, Dronkers and Fleischmann (2010) have shown that an individual's religion is the best indicator of these religious effects, but that the dominant religion of the origin country is a good proxy for this individual effect.

\subsection{Gender equality as an explanation of the effect of religion on educational performance} The level of gender equality of the origin country explains the important effects of the dominant religion. Table $\mathrm{C} 2$ of Appendix $\mathrm{C}$ shows the effects of the dominant religion in the origin countries without a control for gender equality. Islam has a negative significant effect on the educational performance of male pupils ( 25 points lower than male migrant pupils from Latin Christian origin countries) and an even stronger on the reading scores of female migrant pupils from Islamic countries $(-32=-25-7$ points). In addition, migrant children from Orthodox Christian origin countries score around 20 points lower than migrants children from Latin Christian origin countries. Without control for societal gender equality, the positive effect of migrants' children coming from origin countries with Hinduism as the dominant religion is smaller ( 30 or 40 points instead of 50 points). The same holds for migrant pupils from origin countries without a dominant religion, although the difference is smaller (10 points).

These results show that the unequal gender norm in the Islamic countries is a valid explanation for the low educational performance of male and female migrant pupils from countries with Islam as its dominant religion. Male and female pupils from Hindu countries might perform even better educationally if the gender norms and values of Hinduism were more egalitarian. Religion does not need to be a "black box" of cultural phenomena; its various aspects can be analyzed (gender equality, economic values, authority) and their importance in the behavior of adherents estimated.

\subsection{Gender equality as a powerful indicator}

The GEM - which combines variables such as women's share of parliamentary seats and ministerial positions, as well as managerial, senior official, and legislative jobs; their share of technical and professional jobs; and gender income differences - seems to be a powerful macro predictor of educational performance. The level of gender equality in the origin country seems to be a substantial macro indicator for its educational development, irrespective of other, broader macro indicators such as the HDI or more specialized indicators such as YCE. This finding is quite remarkable and requires further study. A possible explanation of the strength of the GEM index is that a society's gender balance is a more up- 
to-date indicator of the society's modernity and openness than life expectancies; literacy rates; enrollment in primary, secondary, and tertiary education; and GDP.

It is important to note that the societal gender equality of the origin country affects not only the educational performance of migrants' daughters, but also that of the migrants' sons. Gender equality is relevant for the educational opportunities of not just women but also both sexes. The explanation may be that the sons of migrants from countries with low levels of gender equality still have traditional gender roles and norms (e.g., a strong emphasis on honor and physical masculinity) that contradict the modern gender norms and roles of their destination societies (e.g., cooperation and negotiation). This conflict between the migrants' own gender norms of their origin countries and surrounding gender norms and roles may be detrimental to their educational performance.

\subsection{Superior female educational performance}

Our results also suggest that migrants' daughters perform better educationally than comparable migrants' sons. Female migrant pupils have reading scores nearly 44 points higher than comparable male migrant pupils, which is slightly more than the difference in the reading scores between female and male native pupils (37 points). Migrant boys have higher math scores than comparable migrant girls (by about eight points), which is slightly less than the 14-point difference between the math scores of native male and female pupils. Although a female advantage of 10 points is not much, it is still substantial and fascinating. Possible explanations for this advantage include the higher second language processing abilities of females (Payne \& Lynn, 2011) and the human preference for patrilocality, with males staying in their natal groups while females migrate (Ember \& Ember, 1985; Fox, 1967; Murdock, 1985), which may have given females greater adaptability to new social environments.

\subsection{Caveats}

To provide more robust tests of hypotheses concerning the effects of educational systems, information from a larger number of OECD destination countries is necessary. Given the importance of migrant children's success in education, it is unfortunate that OECD destination countries such as Canada, France, England, the United States, and Sweden do not collect and make available the information needed for such an analysis, which limits our sample's comparability strength to some extent. This is not only a drawback for the scientific study of the educational achievement of the children of migrants, but also socially and politically irresponsible to deny or ignore the importance of the macro characteristics of origin and destination countries (e.g., European Commission, 2008; OECD, 2006, 2012). However, our results for a restricted number of OECD countries can be considered representative of all OECD countries. In an unpublished analysis (results available upon request), we compared the educational performance of migrant pupils in OECD countries with and without detailed information about their parents' and their own birth countries. We found that the strength of relevant variables such as parental background, migrant generation, and home language was the same in both groups of OECD countries. This suggests that the forced selection of OECD countries in our analysis does not bias our results in comparison with all OECD countries.

The results may be different for non-OECD countries such as China and Latin American countries (Kornder \& Dronkers, 2012) as destination countries, because the nature of migration to these countries is different. It would be worthwhile to repeat this analysis for different groups of non-OECD countries.

Another important improvement for future research would be the inclusion of a school level between the levels of the countries of origin and destination and the individual pupil. Dunne (2010) and Dronkers, van der Velden, and Dunne (2012) independently showed that 
school characteristics such as school composition and ethnic and social-cultural diversity have different effects and implications in different educational systems for the educational achievement of native and migrants' children, although these school-level variables do not explain away the independent effects of the origin and destination countries' macro characteristics. However, it is implausible that the inclusion of a school level would substantially change the gender variation in educational performance analyzed in this article.

Finally, there may exist an unmeasured selectivity of migrants (and thus their children) related to the levels of gender equality in their origin countries. Migrants from origin countries with very low gender equality can have a higher unmeasured ability (e.g., intelligence, personality) than migrants from origin countries with greater gender equality, due to the greater hurdles the former must overcome to settle in OECD countries. This greater ability will not be reflected by their educational levels (which is included in the variable ESCS), due to the low average level of education in their origin countries. But inclusion of an ability selectivity indicator only strengthens the parameter of the GEM score of the origin countries on educational performance and does not diminish it. Moreover, it is implausible that this selectivity differs between the parents of sons or daughters; thus this inclusion will not change the gender variation in educational performance analyzed in this article. 


\section{References}

Abada, T. \& Tenkorang, E. Y. (2009). "Gender differences in educational attainment among children of Canadian immigrants." International Sociology 24, 580-608.

Buchmann, C., DiPrete, T. A. \& McDaniel, A. (2008). "Gender inequalities in education." Annual Review of Sociology 34: 319-337.

Dronkers, J. \& Fleischmann, F. (2010). "The educational attainment of second generation immigrants from different countries of origin in the EU Member-States" In: J. Dronkers (Ed.), Quality and Inequality of Education. Cross-National Perspectives. (pp. 299328). Dordrecht: Springer.

Dronkers, J. \& de Heus, M. (2013a) “Migrants' children scientific performance in a double comparative design: The influence of origin, destination, and community." In: $\mathrm{H}$. Meyer \& A. Benavot (Eds.), Who Succeeds at PISA? Oxford: Symposium Books.

Dronkers, J. \& de Heus, M. (2013b). "The educational performance of children of immigrants in sixteen OECD countries.” In: D. J. Besharov, M. H. Lopez \& M. Siegel (Eds.), Trends in Migration and Migration Policy. Oxford: Oxford University Press.

Dronkers, J., van der Velden, R. \& Dunne, A. (2012). "Why are migrant students better off in certain types of educational systems or schools than in others?" European Educational Research Journal 11(1): 11-44.

Dronkers, J. \& de Lange, M. (2012) "Is er een toenemende negatieve relatie tussen alleenstaande moedergezinnen en onderwijsprestaties bij stijgende percentages eenoudergezinnen? Een vergelijking van PISA 2000, 2003 en 2009" [Is there an increasing negative relation between single-motherhood and educational performance by increasing percentages single-parent families? A comparison of PISA 2000, 2003 and 2009]. Pp 211-238 in Tijdschrift voor Sociologie, special issue family sociology, edited by Dimitri Mortelmans \& Anne-Rigt Poortman.

Dunne, A. (2010). Dividing lines: Examining the relative importance of between- and within-school differentiation during lower secondary education. Ph.D. dissertation, European University Institute (Florence).

Ember, M. \& Ember, C. R. (1985). Marriage, Family and Kinship: Comparative Studies of Social Organisation. New Haven, CT: HRAF Press.

European Commission (2008). Migration \& Mobility: Challenges and Opportunities for EU Education Systems. Brussels: European Commission.

Feliciano, C. \& Rumbaut, R. G. (2005). "Gendered paths: Educational and occupational expectations and outcomes among adult children of immigrants." Ethnic and Racial Studies 28: 1087-1118.

Fleischmann, F. \& Kristen, C. (forthcoming). "Gender gaps in the education of the second generation.” In: A. Heath \& Y. Brinbaum (Eds.), Unequal Attainments. Ethnic Educational Inequalities in Ten Western Countries. Oxford: Proceedings of the British Academy.

Fox, R. (1967). Kinship \& Marriage. An Anthropological Perspective. Cambridge: Cambridge University Press.

Fuligni, A. J., Tseng, V. \& Lam, M. (1999), “Attitudes toward family obligations among American adolescents with Asian, Latin American, and European backgrounds." Child Development 70: 1030-1044.

Ganzeboom, H. B. G., de Graaf, P., Treiman, D. J. \& De Leeuw, J. (1992), “A standard international socio-economic index of occupational status." Social Science Research 21: 1-56.

Guiso, L., Monte, F., Sapienza, P. \& Zingales, L. (2008). “Culture, gender, and math.” Science 320: 1164-1165.

Kornder, N. \& Dronkers, J. (2012). Do migrant girls always perform better? Differences between the reading and math scores of 15-year-old daughters and sons of migrants in PISA 
2009 and variations by region of origin and country of destination. ROA Research Memorandum 2012/4, Maastricht University.

Levels, M. \& Dronkers, J. (2008) "Educational performance of native and immigrant children from various countries of origin." Ethnic and Racial Studies 31: 1404-1425.

Levels, M., Dronkers, J., \& Kraaykamp, G. (2008). "Immigrant children's educational achievement in Western countries: Origin, destination, and community effects on mathematical performance." American Sociological Review 73: 835-853.

Marks, G. (2007). "Accounting for the gender gaps in student performance in reading and mathematics: Evidence from 31 countries" Oxford Review of Education 34 1): 89-109.

Murdock, G. P. (1985). "Ethnographic Atlas Variables for Standard Cross-Cultural Sample." World Cultures 1, files STDS09-12.CD, STDS09-12.DAT.

Organisation for Economic Co-operation and Development (2006). Where Immigrant Students Succeed. Pisa 2003. Paris: Organisation for Economic Co-operation and Development.

Organisation for Economic Co-operation and Development (2010). PISA 2009 Results: What Students Know and Can Do. Paris: Organisation for Economic Co-operation and Development.

Organisation for Economic Co-operation and Development (2012). Untapped Skills. Realising the Potential of Immigrant Students. Paris: Organisation for Economic Co-operation and Development.

Payne, T. W. \& Lynn, R. (2011). "Sex differences in second language comprehension." Personality and Individual Differences 50: 434-436.

Portes, A. (1999). "Conclusion: Towards a new world - The origins and effects of transnational activities." Ethnic and Racial Studies 22(2): 463-477.

Portes, A. \& Rumbaut, R. G. (2001). Legacies: The Story of the Immigrant Second Generation. Berkeley, CA: University of California Press.

Raudenbush, S. W. \& Bryk, A. S. (2002). Hierarchical Linear Models: Applications and Data Analysis Methods, 2nd ed. Newbury Park CA: Sage.

Snijders, T. A. B. \& Bosker, R. J. (1999). Multilevel Analysis. An Introduction to Basic and Advanced Multilevel Modeling. London: Sage.

Song, S. \& Robert, P. (2010). "Immigrant student investigation in PISA 2006: A call for a more nuanced examination." Journal for Educational Research Online 2: 32-52.

United Nations Educational, Scientific and Cultural Organization (2006). ISCED 1997: International Standard Classification of Education. Re-edition. Paris: United Nations Educational, Scientific and Cultural Organization.

Van Langen, A. (2005). Unequal Participation in Mathematics and Science Participation. Antwerp: Garant.

Van Tubergen, F., Maas, I. \& H. Flap, H. (2004). "The economic incorporation of migrants in 18 Western societies: Origin, destination, and community effects." American Sociological Review 69: 704-727.

Zhou, M. \& Bankston, C. L. (2001). "Family pressure and the educational experience of the daughters of Vietnamese refugees." International Migration 39: 133-151. 
Table 1: Reading and math scores of migrant male and female pupils by country of destination (with means, standard deviations, and numbers of male and female pupils)

\begin{tabular}{|c|c|c|c|c|}
\hline & \multicolumn{2}{|c|}{ Male } & \multicolumn{2}{|c|}{ Female } \\
\hline & Reading & Math & Reading & Math \\
\hline \multirow[t]{3}{*}{ Australia } & 507 & 530 & 542 & 520 \\
\hline & 97 & 90 & 87 & 86 \\
\hline & 474 & 474 & 526 & 526 \\
\hline \multirow[t]{3}{*}{ Austria } & 412 & 467 & 451 & 451 \\
\hline & 93 & 85 & 94 & 84 \\
\hline & 503 & 503 & 497 & 497 \\
\hline \multirow[t]{3}{*}{ Belgium } & 464 & 494 & 493 & 470 \\
\hline & 104 & 99 & 97 & 99 \\
\hline & 531 & 531 & 469 & 469 \\
\hline \multirow[t]{3}{*}{ Czech Republic } & 460 & 500 & 502 & 485 \\
\hline & 103 & 107 & 101 & 101 \\
\hline & 545 & 545 & 455 & 455 \\
\hline \multirow[t]{3}{*}{ Denmark } & 402 & 432 & 430 & 411 \\
\hline & 72 & 72 & 76 & 79 \\
\hline & 446 & 446 & 554 & 554 \\
\hline \multirow[t]{3}{*}{ Finland } & 479 & 521 & 528 & 513 \\
\hline & 89 & 82 & 85 & 86 \\
\hline & 490 & 490 & 510 & 510 \\
\hline \multirow[t]{3}{*}{ Germany } & 431 & 473 & 479 & 465 \\
\hline & 94 & 93 & 85 & 88 \\
\hline & 506 & 506 & 494 & 494 \\
\hline \multirow[t]{3}{*}{ Greece } & 419 & 431 & 468 & 427 \\
\hline & 93 & 85 & 81 & 70 \\
\hline & 504 & 504 & 496 & 496 \\
\hline \multirow[t]{3}{*}{ Israel } & 480 & 477 & 509 & 459 \\
\hline & 106 & 104 & 97 & 92 \\
\hline & 446 & 446 & 554 & 554 \\
\hline \multirow[t]{3}{*}{ Liechtenstein } & 484 & 554 & 519 & 528 \\
\hline & 80 & 83 & 72 & 79 \\
\hline & 522 & 522 & 478 & 478 \\
\hline \multirow[t]{3}{*}{ Luxembourg } & 427 & 474 & 473 & 461 \\
\hline & 105 & 96 & 100 & 89 \\
\hline & 492 & 492 & 508 & 508 \\
\hline \multirow[t]{3}{*}{ Netherlands } & 472 & 501 & 499 & 487 \\
\hline & 85 & 83 & 79 & 80 \\
\hline & 486 & 486 & 514 & 514 \\
\hline \multirow[t]{3}{*}{ New Zealand } & 520 & 542 & 556 & 528 \\
\hline & 101 & 95 & 86 & 83 \\
\hline & 545 & 545 & 455 & 455 \\
\hline \multirow[t]{3}{*}{ Norway } & 460 & 483 & 530 & 497 \\
\hline & 101 & 85 & 87 & 79 \\
\hline & 576 & 576 & 424 & 424 \\
\hline \multirow[t]{3}{*}{ Portugal } & 479 & 498 & 512 & 483 \\
\hline & 82 & 89 & 70 & 82 \\
\hline & 454 & 454 & 546 & 546 \\
\hline \multirow[t]{3}{*}{ Scotland } & 531 & 542 & 534 & 515 \\
\hline & 102 & 98 & 57 & 65 \\
\hline & 507 & 507 & 493 & 493 \\
\hline \multirow[t]{3}{*}{ Switzerland } & 454 & 508 & 490 & 489 \\
\hline & 88 & 94 & 86 & 90 \\
\hline & 519 & 519 & 481 & 481 \\
\hline Total & 464 & 496 & 500 & 480 \\
\hline & 101 & 97 & 91 & 91 \\
\hline & 8526 & 8526 & 8430 & 8430 \\
\hline
\end{tabular}

Source: Own computation of PISA wave 2009 data (weighted by destination). 
Table 2: Reading and math scores of migrant male and female pupils by country or region of origin (with means, standard deviations, and numbers of male and female pupils)

\begin{tabular}{|c|c|c|c|c|}
\hline & \multicolumn{2}{|c|}{ Male } & \multicolumn{2}{|c|}{ Female } \\
\hline & Reading & Math & Reading & Math \\
\hline \multirow[t]{3}{*}{ Afghanistan } & 369 & 409 & 431 & 413 \\
\hline & 64 & 64 & 76 & 71 \\
\hline & 30 & 30 & 42 & 42 \\
\hline \multirow[t]{3}{*}{ Albania } & 414 & 430 & 469 & 425 \\
\hline & 90 & 85 & 78 & 63 \\
\hline & 356 & 356 & 328 & 328 \\
\hline \multirow[t]{3}{*}{ Australia } & 507 & 524 & 557 & 525 \\
\hline & 111 & 98 & 79 & 72 \\
\hline & 64 & 64 & 62 & 62 \\
\hline \multirow[t]{3}{*}{ Austria } & 485 & 544 & 538 & 536 \\
\hline & 77 & 79 & 64 & 71 \\
\hline & 143 & 143 & 125 & 125 \\
\hline \multirow[t]{3}{*}{ Belgium } & 503 & 552 & 532 & 521 \\
\hline & 91 & 90 & 84 & 86 \\
\hline & 48 & 48 & 63 & 63 \\
\hline \multirow[t]{3}{*}{ Brazil } & 471 & 496 & 506 & 480 \\
\hline & 87 & 96 & 69 & 81 \\
\hline & 80 & 80 & 85 & 85 \\
\hline \multirow[t]{3}{*}{ Cape Verde } & 343 & 395 & 409 & 406 \\
\hline & 110 & 95 & 111 & 89 \\
\hline & 17 & 17 & 22 & 22 \\
\hline \multirow[t]{3}{*}{ Denmark } & 442 & 474 & 530 & 508 \\
\hline & 114 & 94 & 87 & 83 \\
\hline & 229 & 229 & 160 & 160 \\
\hline \multirow[t]{3}{*}{ Ethiopia } & 394 & 376 & 422 & 364 \\
\hline & 79 & 70 & 106 & 87 \\
\hline & 83 & 83 & 98 & 98 \\
\hline \multirow[t]{3}{*}{ France } & 477 & 507 & 516 & 495 \\
\hline & 102 & 102 & 95 & 92 \\
\hline & 255 & 255 & 261 & 261 \\
\hline \multirow[t]{3}{*}{ Germany } & 493 & 538 & 526 & 518 \\
\hline & 92 & 86 & 87 & 89 \\
\hline & 366 & 366 & 360 & 360 \\
\hline \multirow[t]{3}{*}{ Greece } & 432 & 486 & 466 & 443 \\
\hline & 122 & 119 & 87 & 99 \\
\hline & 15 & 15 & 16 & 16 \\
\hline \multirow[t]{3}{*}{ India } & 573 & 567 & 560 & 528 \\
\hline & 86 & 72 & 62 & 78 \\
\hline & 77 & 77 & 78 & 78 \\
\hline \multirow[t]{3}{*}{ Iraq \& Iran } & 420 & 450 & 423 & 406 \\
\hline & 74 & 76 & 73 & 74 \\
\hline & 97 & 97 & 80 & 80 \\
\hline \multirow[t]{3}{*}{ Italy } & 451 & 502 & 485 & 475 \\
\hline & 82 & 87 & 83 & 91 \\
\hline & 242 & 242 & 217 & 217 \\
\hline \multirow[t]{3}{*}{ Korea } & 505 & 559 & 533 & 542 \\
\hline & 92 & 87 & 92 & 96 \\
\hline & 61 & 61 & 46 & 46 \\
\hline \multirow[t]{3}{*}{ Lebanon } & 406 & 434 & 421 & 394 \\
\hline & 74 & 70 & 73 & 74 \\
\hline & 66 & 66 & 82 & 82 \\
\hline Liechtenstein & 469 & 529 & 537 & 544 \\
\hline
\end{tabular}




\begin{tabular}{|c|c|c|c|c|}
\hline & 97 & 109 & 67 & 78 \\
\hline & 5 & 5 & 4 & 4 \\
\hline \multirow[t]{3}{*}{ Netherlands } & 485 & 524 & 532 & 528 \\
\hline & 79 & 79 & 80 & 85 \\
\hline & 77 & 77 & 56 & 56 \\
\hline \multirow[t]{3}{*}{ Netherlands Antilles } & 466 & 493 & 512 & 503 \\
\hline & 87 & 80 & 54 & 57 \\
\hline & 68 & 68 & 47 & 47 \\
\hline \multirow[t]{3}{*}{ New Zealand } & 485 & 506 & 524 & 450 \\
\hline & 100 & 87 & 88 & 87 \\
\hline & 105 & 105 & 120 & 120 \\
\hline \multirow[t]{3}{*}{ Pakistan \& Bangladesh } & 496 & 513 & 513 & 490 \\
\hline & 101 & 105 & 75 & 81 \\
\hline & 283 & 283 & 313 & 313 \\
\hline \multirow[t]{3}{*}{ Philippines } & 485 & 509 & 528 & 503 \\
\hline & 82 & 75 & 79 & 73 \\
\hline & 27 & 27 & 37 & 37 \\
\hline \multirow[t]{3}{*}{ Poland } & 460 & 502 & 496 & 488 \\
\hline & 88 & 96 & 81 & 79 \\
\hline & 90 & 90 & 101 & 101 \\
\hline \multirow[t]{3}{*}{ Portugal } & 410 & 460 & 453 & 448 \\
\hline & 93 & 88 & 85 & 78 \\
\hline & 299 & 299 & 320 & 320 \\
\hline \multirow[t]{3}{*}{ Romania } & 424 & 470 & 488 & 490 \\
\hline & 89 & 84 & 91 & 71 \\
\hline & 22 & 22 & 15 & 15 \\
\hline \multirow[t]{3}{*}{ Czech \& Slovak Republics } & 460 & 500 & 493 & 477 \\
\hline & 107 & 114 & 106 & 106 \\
\hline & 408 & 408 & 355 & 355 \\
\hline \multirow[t]{3}{*}{ Vietnam } & 469 & 514 & 550 & 535 \\
\hline & 81 & 82 & 70 & 70 \\
\hline & 67 & 67 & 65 & 65 \\
\hline \multirow{3}{*}{ Somalia } & 391 & 413 & 444 & 427 \\
\hline & 75 & 78 & 74 & 74 \\
\hline & 35 & 35 & 26 & 26 \\
\hline \multirow[t]{3}{*}{ South Africa } & 514 & 536 & 558 & 533 \\
\hline & 96 & 82 & 80 & 76 \\
\hline & 78 & 78 & 75 & 75 \\
\hline \multirow[t]{3}{*}{ Spain } & 490 & 525 & 509 & 501 \\
\hline & 80 & 85 & 68 & 72 \\
\hline & 43 & 43 & 57 & 57 \\
\hline \multirow[t]{3}{*}{ Suriname } & 486 & 517 & 513 & 498 \\
\hline & 94 & 87 & 76 & 75 \\
\hline & 93 & 93 & 101 & 101 \\
\hline \multirow[t]{3}{*}{ Sweden } & 477 & 506 & 526 & 498 \\
\hline & 91 & 84 & 77 & 74 \\
\hline & 642 & 642 & 573 & 573 \\
\hline \multirow[t]{3}{*}{ Switzerland } & 493 & 573 & 535 & 559 \\
\hline & 76 & 85 & 67 & 68 \\
\hline & 234 & 234 & 191 & 191 \\
\hline \multirow[t]{3}{*}{ Turkey } & 402 & 449 & 436 & 430 \\
\hline & 84 & 81 & 83 & 83 \\
\hline & 733 & 733 & 783 & 783 \\
\hline \multirow[t]{3}{*}{ United Kingdom } & 527 & 545 & 558 & 531 \\
\hline & 89 & 84 & 82 & 78 \\
\hline & 495 & 495 & 463 & 463 \\
\hline United States of America & 553 & 555 & 546 & 512 \\
\hline
\end{tabular}




\begin{tabular}{|c|c|c|c|c|}
\hline & 94 & 93 & 89 & 84 \\
\hline & 70 & 70 & 119 & 119 \\
\hline \multirow{3}{*}{ Samoa } & 427 & 441 & 484 & 444 \\
\hline & 100 & 89 & 84 & 77 \\
\hline & 70 & 70 & 65 & 65 \\
\hline \multirow[t]{3}{*}{ African country with Portuguese as the official language } & 481 & 499 & 513 & 484 \\
\hline & 81 & 87 & 71 & 82 \\
\hline & 356 & 356 & 440 & 440 \\
\hline \multirow[t]{3}{*}{ Congo } & 482 & 503 & 499 & 468 \\
\hline & 112 & 111 & 103 & 100 \\
\hline & 93 & 93 & 86 & 86 \\
\hline \multirow[t]{3}{*}{ Algeria, Morocco, \&Tunisia } & 448 & 477 & 479 & 451 \\
\hline & 89 & 83 & 73 & 77 \\
\hline & 217 & 217 & 229 & 229 \\
\hline \multirow[t]{3}{*}{ One of the former USSR republics } & 466 & 487 & 509 & 479 \\
\hline & 96 & 89 & 93 & 91 \\
\hline & 853 & 853 & 892 & 892 \\
\hline \multirow[t]{3}{*}{ One of the former Yugoslav republics } & 417 & 467 & 463 & 455 \\
\hline & 89 & 88 & 84 & 82 \\
\hline & 520 & 520 & 530 & 530 \\
\hline \multirow[t]{3}{*}{ Arabic region (including the Middle East) } & 546 & 574 & 505 & 521 \\
\hline & 37 & 29 & 74 & 37 \\
\hline & 56 & 56 & 42 & 42 \\
\hline \multirow[t]{3}{*}{ China } & 545 & 562 & 563 & 552 \\
\hline & 112 & 107 & 65 & 65 \\
\hline & 258 & 258 & 199 & 199 \\
\hline \multirow[t]{3}{*}{ Total } & 464 & 496 & 500 & 481 \\
\hline & 101 & 97 & 91 & 91 \\
\hline & 8526 & 8526 & 8430 & 8430 \\
\hline
\end{tabular}

Source: Own computation of PISA wave 2009 data (weighted by destination country). 
Table 3: Descriptive statistics

\begin{tabular}{|c|c|c|c|c|}
\hline & Minimum & Maximum & Mean & Std. Deviation \\
\hline \multicolumn{5}{|l|}{ Individual } \\
\hline Female & 0.00 & 1.00 & 0.50 & 0.50 \\
\hline Weight & 0.28 & 14.08 & 2.67 & 3.38 \\
\hline Reading test & 59.29 & 823.70 & 481.89 & 98.00 \\
\hline Math test & 131.34 & 869.93 & 488.75 & 94.51 \\
\hline Error math & 0.00 & 7026.80 & 810.68 & 651.34 \\
\hline Error reading test & 0.00 & 5940.67 & 553.74 & 443.62 \\
\hline Mixed parental marriage & 0.00 & 1.00 & 0.43 & 0.49 \\
\hline Missing value dummy mixed marriage & 0.00 & 1.00 & 0.06 & 0.24 \\
\hline Parental ECSC missing & 0.00 & 1.00 & 0.01 & 0.11 \\
\hline Parental ESCS score & -5.71 & 3.09 & -0.06 & 0.99 \\
\hline Nuclear family & 0.00 & 1.00 & 0.77 & 0.42 \\
\hline Migrant $1^{\text {st }}$ generation same language & 0.00 & 1.00 & 0.13 & 0.34 \\
\hline Migrant $1^{\text {st }}$ generation not same language & 0.00 & 1.00 & 0.12 & 0.33 \\
\hline Migrant $1^{\text {st }}$ generation missing language & 0.00 & 1.00 & 0.03 & 0.16 \\
\hline Migrant $2^{\text {nd }}$ generation same language & 0.00 & 1.00 & 0.49 & 0.50 \\
\hline Migrant $2^{\text {nd }}$ generation not same language & 0.00 & 1.00 & 0.16 & 0.37 \\
\hline Migrant $2^{\text {nd }}$ language missing & 0.00 & 1.00 & 0.06 & 0.25 \\
\hline \multicolumn{5}{|l|}{ Origin country or region } \\
\hline Gender Empowerment Index (GEM) & 16.30 & 90.90 & 61.53 & 18.85 \\
\hline Human Development Index (HDI) & 28.40 & 93.50 & 73.64 & 14.54 \\
\hline Year of Compulsory Education (YCE) & 4.00 & 12.00 & 8.78 & 1.78 \\
\hline Expected Years of Schooling (EYS) & 0.68 & 21.00 & 13.65 & 3.03 \\
\hline Latin Christian & 0.00 & 1.00 & 0.54 & 0.50 \\
\hline Eastern Christian & 0.00 & 1.00 & 0.08 & 0.23 \\
\hline Non-religious & 0.00 & 1.00 & 0.04 & 0.20 \\
\hline Hindu & 0.00 & 1.00 & 0.01 & 0.10 \\
\hline Mixed religion & 0.00 & 1.00 & 0.11 & 0.29 \\
\hline Islam & 0.00 & 1.00 & 0.22 & 0.42 \\
\hline \multicolumn{5}{|l|}{ Country of destination } \\
\hline Average native reading score destination countries & 477.64 & 533.64 & 504.48 & 14.30 \\
\hline Average native math score destination countries & 447.42 & 548.15 & 512.03 & 25.25 \\
\hline Gender Empowerment Index (GEM) & 66.40 & 90.60 & 81.17 & 7.68 \\
\hline
\end{tabular}

Source: Own computation of PISA wave 2009 data (weighted by destination country). 
Table 4: Effects of gender, individual characteristics, and the GEM of the origin and destination countries on the reading scores of the children of migrants

\begin{tabular}{|c|c|c|c|c|c|c|}
\hline & $\begin{array}{r}\text { Model 1: } \\
\text { Gender, } \\
\text { native } \\
\text { average } \\
\& \\
\text { individual }\end{array}$ & $\begin{array}{r}\text { Model 2: } \\
1 \text { \& GEM } \\
\text { origin } \\
\& \\
\text { Gender*GEM }\end{array}$ & $\begin{array}{r}\text { Model 3: } \\
1 \text { \& GEM } \\
\text { destination } \\
\& \\
\text { Gender*GEM }\end{array}$ & $\begin{array}{r}\text { Model 4: } \\
1 \text { \& GEM } \\
\text { destination } \\
\& \text { origin } \\
\& \\
\text { Gender*GEM }\end{array}$ & $\begin{array}{r}\text { Model 5: } \\
4 \& \text { HDI, } \\
\text { YCS, YCE } \\
\text { origin }\end{array}$ & $\begin{array}{r}\text { Model 6: } \\
4 \& \\
\text { religion }\end{array}$ \\
\hline \multicolumn{7}{|l|}{ Individual } \\
\hline Female & $\begin{array}{r}43.73^{* *} \\
(2.85) \\
\end{array}$ & $44.14 * *(2.85)$ & $44.72 * *(2.85)$ & $44.12 * *(2.85)$ & $44.12 * *(2.85)$ & $\begin{array}{r}44.23^{* *} \\
(2.85)\end{array}$ \\
\hline $\begin{array}{l}\text { Mixed parental } \\
\text { marriage }\end{array}$ & $\begin{array}{r}5.60^{* *} \\
(1.68) \\
\end{array}$ & $5.10 * *(1.68)$ & $5.62 * *(1.68)$ & $5.08 * *(1.68)$ & $5.02 * *(1.68)$ & $\begin{array}{r}5.32 * * \\
(1.68) \\
\end{array}$ \\
\hline $\begin{array}{l}\text { Missing mixed parental } \\
\text { marriage }\end{array}$ & $0.60(2.49)$ & $0.27(2.50)$ & $0.67(2.49)$ & $0.33(2.50)$ & $0.29(2.50)$ & $0.42(2.49)$ \\
\hline Parental ESCS score & $\begin{array}{r}27.27^{* *} \\
(0.71)\end{array}$ & $27.20^{* *}(0.71)$ & $27.29 * *(0.71)$ & $27.22 * *(0.71)$ & $27.21 * *(0.71)$ & $\begin{array}{r}27.15^{* *} \\
(0.71)\end{array}$ \\
\hline $\begin{array}{l}\text { Missing parental ESCS } \\
\text { score }\end{array}$ & $\begin{array}{r}-58.31 * * \\
(5.35) \\
\end{array}$ & $\begin{array}{r}-58.31^{* *} \\
(5.35) \\
\end{array}$ & $-58.23 *(5.35)$ & $-58.21 * *(5.35)$ & $\begin{array}{r}-58.23^{* *} \\
(5.35) \\
\end{array}$ & $\begin{array}{r}-57.97 * * \\
(5.35) \\
\end{array}$ \\
\hline Nuclear family & $\begin{array}{r}18.00^{* *} \\
(2.09)\end{array}$ & $18.00^{* *}(2.09)$ & $18.00 * *(2.09)$ & $18.00 * *(2.09)$ & $18.01 * *(2.09)$ & $\begin{array}{r}18.15^{* *} \\
(2.09)\end{array}$ \\
\hline Nuclear family*Female & $\begin{array}{r}-6.79 * * \\
(2.92)\end{array}$ & $-6.89 * *(2.92)$ & $-6.77 * *(2.92)$ & $-6.86^{* *}(2.92)$ & $-6.87 * *(2.92)$ & $\begin{aligned}-6.93 * * \\
(2.92)\end{aligned}$ \\
\hline $\begin{array}{l}1^{\text {st }} \text { generation not same } \\
\text { language } \S\end{array}$ & $\begin{array}{r}-28.49 * * \\
(2.64)\end{array}$ & $\begin{array}{r}-28.04 * * \\
(2.65)\end{array}$ & $-28.49 * *(2.64)$ & $-28.00 * *(2.65)$ & $\begin{array}{r}-27.95 * * \\
(2.65)\end{array}$ & $\begin{array}{r}-29.03^{* *} \\
(2.65)\end{array}$ \\
\hline $\begin{array}{l}1^{\text {st }} \text { generation missing } \\
\text { language } \S\end{array}$ & $\begin{array}{r}-59.67 * * \\
(4.21)\end{array}$ & $\begin{array}{r}-59.29 * * \\
(4.21)\end{array}$ & $-59.68 * *(4.21)$ & $-59.68 * *(4.21)$ & $\begin{array}{r}-59.23 * * \\
(4.21)\end{array}$ & $\begin{array}{r}-59.72 * * \\
(4.21)\end{array}$ \\
\hline $\begin{array}{l}2^{\text {nd }} \text { generation same } \\
\text { language } \S\end{array}$ & $\begin{array}{r}5.92 * * \\
(2.45) \\
\end{array}$ & $6.52 * *(2.46)$ & $5.95 * *(2.45)$ & $6.58 * *(2.45)$ & $6.57 * *(2.46)$ & $\begin{array}{r}6.27 * * \\
(2.46) \\
\end{array}$ \\
\hline $\begin{array}{l}2^{\text {nd }} \text { generation same } \\
\text { language*Female }\end{array}$ & $\begin{array}{r}-5.26^{* *} \\
(2.42)\end{array}$ & $-5.97 * *(2.44)$ & $-5.98 * *(2.44)$ & $-5.26^{* *}(2.42)$ & $-5.95 * *(2.44)$ & $\begin{array}{r}-6.03^{* *} \\
(2.44)\end{array}$ \\
\hline $\begin{array}{l}2^{\text {nd }} \text { generation not same } \\
\text { language } \S\end{array}$ & $\begin{array}{r}-11.01 * * \\
(2.52)\end{array}$ & $\begin{array}{r}-10.68 * * \\
(2.52)\end{array}$ & $-10.98 * *(2.52)$ & $-10.63 * *(2.52)$ & $\begin{array}{r}-10.62 * * \\
(2.52)\end{array}$ & $\begin{array}{r}-11.28 * * \\
(2.52)\end{array}$ \\
\hline $\begin{array}{l}2^{\text {nd }} \text { generation language } \\
\text { missing } \S\end{array}$ & $\begin{array}{r}-45.96 * * \\
(3.07) \\
\end{array}$ & $\begin{array}{r}-45.58 * * \\
(3.07) \\
\end{array}$ & $-45.95 * *(3.06)$ & $-45.54 * *(3.07)$ & $\begin{array}{r}-45.52 * * \\
(3.07) \\
\end{array}$ & $\begin{array}{r}-46.02 * * \\
(3.06) \\
\end{array}$ \\
\hline \multicolumn{7}{|l|}{ Destination country } \\
\hline $\begin{array}{l}\text { Average native reading } \\
\text { score }\end{array}$ & $0.45(0.32)$ & $0.36(0.31)$ & $1.13 * *(0.42)$ & $1.07 * *(0.40)$ & $1.02 * *(0.41)$ & $\begin{array}{r}0.72 * * \\
(0.32) \\
\end{array}$ \\
\hline GEM destination $\dagger$ & & & $-1.61 * *(0.78)$ & $-1.64 * *(0.75)$ & $-1.58 * *(0.75)$ & $-0.90(0.61)$ \\
\hline $\begin{array}{l}\text { GEM } \\
\text { destination*Female } \dagger\end{array}$ & & & $-0.06(0.20)$ & $-0.10(0.20)$ & $-0.10(0.20)$ & $-0.10(0.20)$ \\
\hline \multicolumn{7}{|l|}{ Origin country } \\
\hline GEM origin $\dagger$ & & $0.35 * *(0.14)$ & & $0.36^{* *}(0.14)$ & $0.32(0.21)$ & $\begin{array}{r}0.39^{* *} \\
(0.17)\end{array}$ \\
\hline GEM origin*Female $\dagger$ & & $0.14 * *(0.07)$ & & $0.14 * *(0.07)$ & $0.14 * *(0.07)$ & $\begin{array}{r}0.15^{* *} \\
(0.07) \\
\end{array}$ \\
\hline $\mathrm{HDI} \dagger$ & & & & & $0.15(0.31)$ & \\
\hline $\mathrm{YCE}^{\dagger}$ & & & & & $1.18(1.74)$ & \\
\hline EYS† & & & & & $-0.85(1.45)$ & \\
\hline Eastern Christian $t$ & & & & & & $-8.98(7.95)$ \\
\hline Non-religious $\$$ & & & & & & $\begin{array}{r}47.04 * * \\
(8.36) \\
\end{array}$ \\
\hline Hindu $t$ & & & & & & $\begin{array}{r}50.10^{* *} \\
(16.48) \\
\end{array}$ \\
\hline Mixed religion $\$$ & & & & & & $6.84(8.87)$ \\
\hline Islam & & & & & & $-10.70(8.12)$ \\
\hline Constant & $\begin{array}{r}233.93 \\
(163.72) \\
\end{array}$ & $\begin{array}{r}280.98 \\
(157.13) \\
\end{array}$ & $\begin{aligned}-113.91 \\
(211.91) \\
\end{aligned}$ & $-80.44(202.36)$ & $\begin{array}{r}-55.86 \\
(205.59) \\
\end{array}$ & $\begin{array}{r}94.05 \\
(163.28) \\
\end{array}$ \\
\hline \multicolumn{7}{|l|}{ Variances } \\
\hline Destination & $\begin{array}{c}312.19^{*} \\
(159.40)\end{array}$ & $\begin{array}{c}291.94^{*} \\
(147.68)\end{array}$ & $\begin{array}{r}192.98 \\
(110.40)\end{array}$ & $\begin{array}{r}182.82 \\
(102.74) \\
\end{array}$ & $\begin{array}{r}192.77 \\
(106.43)\end{array}$ & $\begin{array}{l}107.61 \\
(61.67)\end{array}$ \\
\hline Origin & $\begin{array}{r}444.33 * * \\
(83.45) \\
\end{array}$ & $\begin{array}{r}385.89 * * \\
(73.88) \\
\end{array}$ & $\begin{array}{r}448.67 * * \\
(83.72) \\
\end{array}$ & $\begin{array}{r}383.94 * * \\
(73.24)\end{array}$ & $\begin{array}{r}372.99 * * \\
(71.45)\end{array}$ & $\begin{array}{r}221.18^{* *} \\
(46.03)\end{array}$ \\
\hline
\end{tabular}




\begin{tabular}{|c|c|c|c|c|c|c|}
\hline Pupils & $\begin{array}{r}4211.65^{* *} \\
(1407.16) \\
\end{array}$ & \begin{tabular}{r|}
$4174.87 * *$ \\
$(1406.80)$ \\
\end{tabular} & $\begin{array}{r}4221.72 * * \\
(1407.25) \\
\end{array}$ & $\begin{array}{r}4186.78^{* *} \\
(1406.95) \\
\end{array}$ & \begin{tabular}{r|}
$4186.14 * *$ \\
$(1406.86)$ \\
\end{tabular} & $\begin{array}{r}4241.60 * * \\
(1406.98) \\
\end{array}$ \\
\hline Test $(* 1000)$ & $\begin{array}{r}0.001 * * \\
(0.000)\end{array}$ & $\begin{array}{r}0.002 * * \\
(0.000)\end{array}$ & $\begin{array}{r}0.002 * * \\
(0.000)\end{array}$ & $\begin{array}{r}0.002 * * \\
(0.000)\end{array}$ & $\begin{array}{r}0.002 * * \\
(0.000)\end{array}$ & $\begin{array}{r}0.002 * * \\
(0.000)\end{array}$ \\
\hline Log likelihood & 205670 & 205657 & 205666 & 205652 & 205651 & 205611 \\
\hline
\end{tabular}

Source: Own computation with PISA 2009 data, with equal weights for destination countries. § First-generation migrant with the same language as the destination country is the reference category. $\$$ Latin Christian is the reference category. $\dagger$ Centered grand mean. 
Table 5: Effects of gender, individual characteristics, and the GEM of origin and destination countries on the math scores of the children of migrants

\begin{tabular}{|c|c|c|c|c|c|c|}
\hline & $\begin{array}{r}\text { Model 1: } \\
\text { Gender, } \\
\text { native } \\
\text { average } \\
\& \\
\text { Individual } \\
\end{array}$ & $\begin{array}{r}\text { Model 2: } \\
1 \text { \& GEM } \\
\text { origin } \\
\& \\
\text { Gender*GEM }\end{array}$ & $\begin{array}{r}\text { Model 3: } \\
1 \text { \& GEM } \\
\text { destination } \\
\& \\
\text { Gender*GEM }\end{array}$ & $\begin{array}{r}\text { Model 4: } \\
1 \text { \& GEM } \\
\text { destination } \\
\& \text { origin } \\
\& \\
\text { Gender*GEM }\end{array}$ & $\begin{array}{r}\text { Model 5: } \\
4 \text { \& HDI, } \\
\text { YCS, YCE } \\
\text { origin }\end{array}$ & $\begin{array}{r}\text { Model 6: } \\
4 \text { \& } \\
\text { religion }\end{array}$ \\
\hline \multicolumn{7}{|l|}{ Individual } \\
\hline Female & $\begin{array}{r}-7.92 * * \\
(2.54) \\
\end{array}$ & $-7.96 * *(2.54)$ & $-7.92 * *(2.54)$ & $-7.96 * *(2.54)$ & $-7.75 * *(2.54)$ & $\begin{array}{r}-7.86^{* *} \\
(2.54) \\
\end{array}$ \\
\hline $\begin{array}{l}\text { Mixed parental } \\
\text { marriage }\end{array}$ & $\begin{array}{r}7.50^{* *} \\
(1.65) \\
\end{array}$ & $7.56^{* *}(1.65)$ & $7.98 * *(1.64)$ & $7.57 * *(1.65)$ & $7.55^{* *}(1.65)$ & $\begin{array}{r}7.83 * * \\
(1.65) \\
\end{array}$ \\
\hline $\begin{array}{l}\text { Missing mixed parental } \\
\text { marriage }\end{array}$ & $-0.81(2.44)$ & $-1.09(2.44)$ & $-0.75(2.44)$ & $-1.04(2.44)$ & $-1.01(2.44)$ & $-0.96(2.44)$ \\
\hline Parental ESCS score & $\begin{array}{r}26.71 * * \\
(0.92) \\
\end{array}$ & $26.79 * *(0.93)$ & $26.76^{* *}(0.92)$ & $26.83 * *(0.93)$ & $26.62 * *(0.93)$ & $\begin{array}{r}26.83 * * \\
(0.93) \\
\end{array}$ \\
\hline ESCS*Female & $\begin{array}{r}3.29 * * \\
(1.18) \\
\end{array}$ & $3.03 * *(1.23)$ & $3.23 * *(1.19)$ & $2.99 * *(1.23)$ & $3.37 * *(1.24)$ & $\begin{array}{r}3.01 * * \\
(1.23) \\
\end{array}$ \\
\hline $\begin{array}{l}\text { Missing parental ESCS } \\
\text { score }\end{array}$ & $\begin{array}{r}-54.92 * * \\
(5.19) \\
\end{array}$ & $\begin{array}{r}-54.90^{* *} \\
(5.19) \\
\end{array}$ & $-54.92 * *(5.19)$ & $-54.88 * *(5.19)$ & $-54.73 * *(5.19)$ & $\begin{array}{r}-54.73^{* *} \\
(5.18) \\
\end{array}$ \\
\hline Nuclear family & $\begin{array}{r}22.29 * * \\
(2.04) \\
\end{array}$ & $22.25 * *(2.04)$ & $22.27 * *(2.04)$ & $22.23 * *(2.04)$ & $22.32 * *(2.04)$ & $\begin{array}{r}22.37 * * \\
(2.04) \\
\end{array}$ \\
\hline Nuclear family*Female & $\begin{array}{r}-8.88^{* *} \\
(2.86) \\
\end{array}$ & $-8.88 * *(2.86)$ & $-8.88 * *(2.86)$ & $-8.87 * *(2.86)$ & $-9.10 * *(2.86)$ & $\begin{array}{r}-8.94 * * \\
(2.86) \\
\end{array}$ \\
\hline $\begin{array}{l}1^{\text {st }} \text { generation not same } \\
\text { language } \S\end{array}$ & $\begin{array}{r}-18.13 * * \\
(2.58) \\
\end{array}$ & $\begin{array}{r}-17.73 * * \\
(2.58) \\
\end{array}$ & $-18.15 * *(2.58)$ & $-17.71 * *(2.58)$ & $-17.71 * *(2.58)$ & $\begin{array}{r}-18.70 * * \\
(2.58) \\
\end{array}$ \\
\hline $\begin{array}{l}1^{\text {st }} \text { generation missing } \\
\text { language } \S\end{array}$ & $\begin{array}{r}-52.43 * * \\
(4.11) \\
\end{array}$ & $\begin{array}{r}-52.12 * * \\
(4.11) \\
\end{array}$ & $-52.52 * *(4.11)$ & $-52.19 * *(4.11)$ & $-52.25 * *(4.11)$ & $\begin{array}{r}-52.62 * * \\
(4.11) \\
\end{array}$ \\
\hline $\begin{array}{l}2^{\text {nd }} \text { generation same } \\
\text { language } \S\end{array}$ & $\begin{array}{r}5.21 * * \\
(2.07) \\
\end{array}$ & $5.40 * *(2.07)$ & $5.19 * *(2.07)$ & $5.40 * *(2.07)$ & $5.30 * *(2.07)$ & $\begin{array}{r}4.97 * * \\
(2.07) \\
\end{array}$ \\
\hline $\begin{array}{l}2^{\text {nd }} \text { generation not same } \\
\text { language } \S\end{array}$ & $\begin{array}{r}-6.28 * * \\
(2.47) \\
\end{array}$ & $-5.96^{* *}(2.47)$ & $-6.30 * *(2.47)$ & $-5.95 * *(2.47)$ & $-6.03 * *(2.47)$ & $\begin{array}{r}-6.63 * * \\
(2.46) \\
\end{array}$ \\
\hline $\begin{array}{l}2^{\text {nd }} \text { generation language } \\
\text { missing } \S\end{array}$ & $\begin{array}{r}-41.95 * * \\
(3.01) \\
\end{array}$ & $\begin{array}{r}-41.63 * * \\
(3.02) \\
\end{array}$ & $-42.02 * *(3.01)$ & $-41.66 * *(3.02)$ & $-41.71 * *(3.02)$ & $\begin{array}{r}-41.16^{* *} \\
(3.01) \\
\end{array}$ \\
\hline \multicolumn{7}{|l|}{ Destination country } \\
\hline $\begin{array}{l}\text { Average native math } \\
\text { score }\end{array}$ & $\begin{array}{r}0.58 * * \\
(0.20) \\
\end{array}$ & $0.52 * *(0.19)$ & $0.78 * *(0.23)$ & $0.74 * *(0.21)$ & $0.69^{* *}(0.21)$ & $\begin{array}{r}0.73 * * \\
(0.18) \\
\end{array}$ \\
\hline GEM destination $\uparrow$ & & & $-1.29(0.73)$ & $-1.37 *(0.69)$ & $-1.34 * *(0.68)$ & $-1.08 *(0.56)$ \\
\hline $\begin{array}{l}\text { GEM } \\
\text { destination*Female } \dagger\end{array}$ & & & $0.10(0.20)$ & $0.09(0.20)$ & $0.15(0.20)$ & $0.09(0.20)$ \\
\hline \multicolumn{7}{|l|}{ Origin country } \\
\hline GEM origin $\dagger$ & & $0.39 * *(0.16)$ & & $0.41 * *(0.15)$ & $0.15(0.24)$ & $\begin{array}{r}0.58 * * \\
(0.17) \\
\end{array}$ \\
\hline GEM origin*Female $\dagger$ & & $0.06(0.07)$ & & $0.05(0.07)$ & $0.21 * *(0.10)$ & $0.06(0.07)$ \\
\hline $\mathrm{HDI} \dagger$ & & & & & $0.42(0.34)$ & \\
\hline $\mathrm{YCE} \dagger$ & & & & & $2.12(1.98)$ & \\
\hline YCE*Female $\dagger$ & & & & & $-2.35 * *(0.95)$ & \\
\hline EYS† & & & & & $-0.69(1.59)$ & \\
\hline Eastern Christian $\ddagger$ & & & & & & $-11.00(7.82)$ \\
\hline Non-religious & & & & & & $\begin{array}{r}64.02 * * \\
(8.16) \\
\end{array}$ \\
\hline Hindu $\ddagger$ & & & & & & $\begin{array}{r}51.58^{* *} \\
(16.09) \\
\end{array}$ \\
\hline Mixed religion $\$$ & & & & & & $11.57(8.74)$ \\
\hline Islam $\star$ & & & & & & $-3.52(8.13)$ \\
\hline Constant & $\begin{array}{r}191.42 \\
(104.37) \\
\end{array}$ & $\begin{array}{r}223.75 * * \\
(97.31) \\
\end{array}$ & $83.71(117.75)$ & $\begin{array}{r}107.48 \\
(110.52) \\
\end{array}$ & $\begin{array}{r}133.30 \\
(110.55) \\
\end{array}$ & $\begin{array}{r}110.53 \\
(92.34) \\
\end{array}$ \\
\hline \multicolumn{7}{|l|}{ Variances } \\
\hline Destination & $\begin{array}{r}350.09 * * \\
(182.38) \\
\end{array}$ & $\begin{array}{r}282.24 \\
(151.63) \\
\end{array}$ & $\begin{array}{r}283.49 \\
(154.74) \\
\end{array}$ & $\begin{array}{r}237.48 \\
(132.18) \\
\end{array}$ & $\begin{array}{r}232.53 \\
(129.33) \\
\end{array}$ & $\begin{array}{r}213.35^{* *} \\
(104.44) \\
\end{array}$ \\
\hline Origin & $\begin{array}{r}560.11 * * \\
(101.60)\end{array}$ & $\begin{array}{r}512.82 * * \\
(93.84)\end{array}$ & $\begin{array}{r}551.78 * * \\
(100.05)\end{array}$ & $\begin{array}{r}495.53 * * \\
(90.91)\end{array}$ & $\begin{array}{r}478.06^{* *} \\
(88.10)\end{array}$ & $\begin{array}{r}209.28 * * \\
(43.97)\end{array}$ \\
\hline
\end{tabular}




\begin{tabular}{|l|r|r|r|r|r|r|}
\hline Pupils & $3763.18^{* *}$ & $3759.42^{* *}$ & $3756.22^{* *}$ & $3753.87^{* *}$ & $3746.62^{* *}$ & $3763.89^{* *}$ \\
& $(674.31)$ & $(674.29)$ & $(674.22)$ & $(674.23)$ & $(673.92)$ & $(674.35)$ \\
\hline Test $(* 1000)$ & $0.001^{* *}$ & $0.001^{* *}$ & $0.001^{* *}$ & $0.001^{* *}$ & $0.001^{* *}$ & $0.001^{* *}$ \\
& $(0.000)$ & $(0.000)$ & $(0.000)$ & $(0.000)$ & $(0.000)$ & $(0.000)$ \\
\hline Log likelihood & 204778 & 204770 & 204774 & 204766 & 204757 & 204710 \\
\hline
\end{tabular}

Source: Own computation with PISA 2009 data, with equal weights for destination countries. § First-generation migrant with the same language as the destination country is the reference category. $\$$ Latin Christian is the reference category. $\dagger$ Centered grand mean. 


\section{Appendix A: Macro Variables}

\section{Gender Empowerment Measure (GEM)}

The Gender Empowerment Measure (GEM) evaluates women's participation and decisionmaking ability in political and economic forums. Ranging from zero to 100, it combines such variables as women's share of parliamentary seats and ministerial positions, as well as managerial, senior official, and legislative jobs; their share of technical and professional jobs; and gender income differences. See HDR 2009, http://www.undp.org.tr/publicationsDocuments/Table K from_HDR 2009 EN Gender\%20 Empowerment\%20Measure.pdf. Retrieved August 28, 2011, from http://hdr.undp.org/en/statistics/indices/gdi_gem/.

\section{Human Development Index (HDI)}

A country's HDI measures its level of economic development. Ranging from zero to 100, the HDI combines national information on peoples' life expectancies; adult literacy rates; gross enrollment ratios in primary, secondary, and tertiary education; and GDP. See HDR 2009

\section{Years of Compulsory Education (YCE)}

The YCE variable refers to the duration of compulsory schooling in the country of origin. On average, pupils are obliged to attend school for nine years for all the origin countries and areas in our data. The mandatory length of schooling varies considerably between origin countries, from four to 12 years. See the EFA Global Monitoring Report 2011, http://www.unesco.org/new/en/education/themes/leading-the-internationalagenda/efareport/statistics/statistical-tables/.

\section{Expected Years of Schooling (EYS)}

The EYS variable represents the expected number of years a child of school entrance age will spend in school and university, including grade repetitions, if current enrollment patterns in all educational levels (primary, secondary, post-secondary non-tertiary, and tertiary) remain the same. See the UNESCO Institute for Statistics 2011, http://hdr.undp.org.

\section{Religion}

To take into account origin countries' religious backgrounds, dummy variables were created to indicate whether or not at least $40 \%$ of a country's inhabitants are Latin Christian (Catholic and/or Protestant combined), Eastern Orthodox, Hindu or Islam. Countries in which no religious denomination has the support of at least $40 \%$ of the population are classified as nonreligious. Similarly, if two religious groups are represented by at least $40 \%$ of the population, the country is considered mixed. See the CIA World Factbook, https://www.cia.gov/library/publications/the-world-factbook/fields/2122.html\#lu. 


\section{Appendix B: HDI (Macro Variable) Aggregate Compositions}

For aggregated origin areas, macro indicator values are calculated as the average of all country values available for the specific cluster. The following provides detailed information for each aggregate group, using the HDI as an example. The calculation of other aggregate group indicators follows the same group constellation used to calculate the HDI values but sometimes deviates slightly, since indicators were not always available for all the countries that form the various aggregate groups. For more detailed information on specific aggregate group values, please contact the authors.

\section{African country with Portuguese as the official language}

The countries include Angola, Cape Verde, Guinea-Bissau, Mozambique, and São Tomé and Príncipe.

\section{Algeria, Morocco, \& Tunisia}

\section{Caribbean \& Netherlands Antilles}

We use the average of these islands in the Caribbean - that is, the Bahamas, Barbados, Cuba, the Dominican Republic, Haiti, Jamaica, and Trinidad and Tobago-because information about the other Caribbean islands was not available. For the Netherlands Antilles, we average the values for Suriname and the Caribbean islands.

\section{Former USSR}

All states of the former USSR.

\section{Former Yugoslavia}

Bosnia and Herzegovina, Croatia, Macedonia, Montenegro, Serbia, and Slovenia.

\section{External migrants from China to non-Chinese countries}

This group is comprised of emigrants from all regions of China, including mainland China, Hong Kong, Macau, and Taiwan. 


\section{Appendix C: Additional Analyses}

Table C1: Parameters of the interaction between Gender and a single dependent variable, added to the model indicated without other interaction terms

\begin{tabular}{|c|c|c|}
\hline Interaction term with gender & Reading & Math \\
\hline \multicolumn{3}{|l|}{ Added to model 1} \\
\hline Mixed parental marriage*Female & $-1.39(2.47)$ & $0.08(2.41)$ \\
\hline Parental ESCS score*Female & $0.66(1.21)$ & $2.96 * *(1.18)$ \\
\hline Nuclear family*Female & $-6.55 * *(2.92)$ & $-8.17 * *(2.85)$ \\
\hline $1^{\text {st }}$ generation not same language*Female $\S$ & $5.33(3.71)$ & $4.11(3.61)$ \\
\hline $1^{\text {st }}$ generation missing language* Female $\S$ & $2.47(7.53)$ & $-1.20(7.34)$ \\
\hline $2^{\text {nd }}$ generation same language*Female $\S$ & $-5.05 * *(2.41)$ & $-1.08(2.36)$ \\
\hline $2^{\text {nd }}$ generation not same language*Female $\S$ & $2.31(3.06)$ & $-1.02(3.01)$ \\
\hline $2^{\text {nd }}$ generation language missing*Female $\S$ & $-1.12(4.66)$ & $-3.90(4.60)$ \\
\hline Average native reading/math score*Female & $-0.03(0.10)$ & $-0.03(0.05)$ \\
\hline \multicolumn{3}{|l|}{ Added to model 5} \\
\hline HDI*Female $\dagger$ & $-0.11(0.14)$ & $-0.16(0.13)$ \\
\hline EYS*Female $\dagger$ & $-0.03(0.75)$ & $-0.20(0.73)$ \\
\hline YCE*Female $\dagger$ & $-1.51(0.96)$ & $-2.35 * *(0.95)$ \\
\hline \multicolumn{3}{|l|}{ Added to model 6} \\
\hline Eastern Christian origin*Female $\$$ & $3.02(4.60)$ & $5.01(4.51)$ \\
\hline Non-religious origin*Female $\$$ & $-6.29(6.68)$ & $3.33(6.47)$ \\
\hline Hindu origin*Female $\$$ & $-4.58(13.94)$ & $4.97(13.57)$ \\
\hline Mixed religion origin*Female $\$$ & $0.46(5.78)$ & $2.09(5.55)$ \\
\hline Islamic origin*Female $t$ & $-2.61(4.62)$ & $-6.87(4.54)$ \\
\hline
\end{tabular}

Source: Own computation with PISA 2009 data, with equal weights for destination countries. § First-generation migrant with the same language as the destination country is the reference category. $\$$ Latin Christian is the reference category. $\dagger$ Centered grand mean.

Table C2: Parameters of religion and their interaction terms with gender, controlled for all other variables of model 1

\begin{tabular}{|c|c|c|}
\hline & Reading & Math \\
\hline Eastern Christian $\ddagger$ & $-17.15 * *(4.66)$ & $-21.94 * *(8.43)$ \\
\hline Eastern Christian*Female $\$$ & $0.12(4.66)$ & $3.12(4.59)$ \\
\hline Non-religious $\$$ & $45.01 * *(8.71)$ & $53.16^{* *}(8.87)$ \\
\hline Non-religious*Female $\$$ & $-9.36(6.72)$ & $2.24(6.44)$ \\
\hline Hindu $\$$ & $40.54 * *(17.63)$ & $30.63(18.03)$ \\
\hline Hindu*Female $\$$ & $-10.34(13.81)$ & $3.32(13.39)$ \\
\hline Mixed religion $\$$ & $1.65(9.06)$ & $0.66(9.34)$ \\
\hline Mixed religion*Female $\$$ & $-2.91(5.62)$ & $-1.05(5.36)$ \\
\hline Islam & $-24.63 * *(5.96)$ & $-24.85 * *(6.16)$ \\
\hline Islam*Female $\ddagger$ & $-6.95 *(3.43)$ & $-4.69(3.45)$ \\
\hline
\end{tabular}

Source: Own computation with PISA 2009 data, with equal weights for destination countries. $\$$ Latin Christian is the reference category. The parameters of the other variables of model 1 are not shown.

Table C3: Parameters of the GEM difference between origin and destination in combination with the GEM of the origin or destination countries, controlled for all other variables of model 4

\begin{tabular}{|l|r|r|r|r|}
\hline & \multicolumn{2}{|c|}{ Reading } & \multicolumn{2}{|c|}{ Math } \\
\hline GEM difference origin-destination $\dagger$ & $-1.64^{* *}(0.75)$ & $-0.36^{* *}(0.14)$ & $-1.37 *(0.69)$ & $-0.41^{* *}(0.15)$ \\
\hline GEM difference origin-destination*Female $\dagger$ & $-0.10(0.20)$ & $-0.14^{* *}(0.07)$ & $0.09(0.20)$ & $-0.05(0.07)$ \\
\hline GEM destination $\dagger$ & & $-1.28(0.75)$ & & $-0.96(0.70)$ \\
\hline GEM destination*Female $\dagger$ & & $0.04(0.21)$ & & $0.14(0.20)$ \\
\hline GEM origin $\dagger$ & & & $-0.96(0.70)$ & \\
\hline GEM origin*Female $\dagger$ & $-1.28(0.75)$ & & $0.14(0.20)$ & \\
\hline
\end{tabular}

Source: Own computation with PISA 2009 data, with equal weights for destination countries. $\dagger$ Centered grand mean. The parameters of the other variables of model 4 are not shown. 
Table C4: Correlations between the dominant religion and GEM scores of the origin and destination countries

\begin{tabular}{|l|r|r|}
\hline Dominant religion & GEM origin & GEM destination \\
\hline Latin Christianity & 0.73 & 0.12 \\
\hline Eastern Christianity & -0.08 & -0.11 \\
\hline No religion & -0.09 & -0.05 \\
\hline Hinduism & -0.12 & 0.00 \\
\hline Mixed religion & -0.15 & -0.14 \\
\hline Islam & -0.65 & 0.04 \\
\hline
\end{tabular}

Source: Own computation with PISA 2009 data, with equal weights for destination countries. 